\title{
Protestantism in Russia During the Eighteenth and Early Nineteenth Centuries: Introductory Remarks
}

\author{
Ingrid Schierle \\ Universität Tübingen \\ ingrid.schierle@uni-tuebingen.de
}

\begin{abstract}
:
В предисловии к номеру приведен обзор истории лютеран и рецепции протестантских учений в России.
\end{abstract}

Keywords:

Protestantism, Pietism, heresy, religious education

In October 1517 Martin Luther nailed his 95 theses to the door of All Saints' Church in Wittenberg. His criticism of the practice of selling indulgences and his call for a renewal of the Church helped set the Reformation in motion. Today the repercussions that the Reformation had around the world continue to be a subject of much scholarly interest. In the historiography of Russia there are studies devoted to the reception of Reformation theologians, particularly Luther, and the development of Protestantism in the multinational Russian Empire. Gregory Freeze has reviewed the history of "Lutheranism in Russia" from the eighteenth century until the beginning of the twentieth century. ${ }^{1}$

Direct encounters between Orthodoxy and Protestantism started in the seventeenth century with the immigration of Protestant doctors, apothecaries and other "specialists" to Russia. ${ }^{2}$ In 1702 Peter I issued a call encouraging foreigners to join his service, regardless of which Christian creed they followed. ${ }^{3}$ Outwardly, the most visible sign of the new Protestant congregations were the churches and schools they built. The "Nemetskaiia sloboda" (Foreign Quarter) in Moscow was a source of influence, as is evident in the case of Dimitrii Tveretinov, a doctor practising in this district. In 1713 Tveretinov faced charges of heresy because he had used Protestant arguments against the prevailing dogmas of the Orthodox Church in his teaching. ${ }^{4}$

\footnotetext{
${ }^{1}$ Gregory Freeze, "Lutheranism in Russia: Critical Reassessment," in Hans Medick, Peer Schmidt (eds.), Luther zwischen den Kulturen (Göttingen: Vandenhoeck \& Ruprecht, 2004), 297-317; Ol'ga Kurilo, Liuterane v Rossii XVI-XX vv. (Moscow: Fond "Liuteranskoe nasledie," 2002).

${ }^{2}$ Hans Rothe, Religion und Kultur in den Regionen des russischen Reiches im 18. Jahrhundert. Erster Versuch einer Grundlegung (Opladen: Westdeutscher Verlag, 1984) 16-19.

3 Pis'ma i bumagi Imperatora Petra Velikago, vol. 2 (1702-1703) (St. Petersburg: Gosudarstvennaia tipografiia, 1889), 39; Hans-Heinrich Nolte, "Verständnis und Bedeutung der religiösen Toleranz in Rußland," Jahrbücher für Geschichte Osteuropas 17 (1969): 494-530, here 513-5.

${ }^{4}$ Ludolf Müller, Die Kritik des Protestantismus in der russischen Theologie vom 16. bis zum 18. Jahrhundert (Wiesbaden: Akademie der Wissenschaften und der Literatur, 1951), 60-5; Elena 
Since the beginning of the eighteenth century, Halle Pietists had already established close ties to Russia. ${ }^{5}$ The Pietist principles of an "inner life" and a praxis pietatis were highly compatible with devout traditions of self-discipline in Orthodoxy. ${ }^{6}$

With the annexation of Estonia and Livonia (formerly provinces of Sweden) in 1710, regions with a strong Protestant presence became part of the Russian Empire for the first time. ${ }^{7}$ The first dynastic ties with the Protestant nobility were cemented in 1711, when Tsarevich Aleksei married the Lutheran princess Charlotte Christine von Braunschweig-Wolfenbüttel. ${ }^{8}$ During the reign of Catherine II, herself a convert to the Orthodox faith from Lutheranism, the incorporation of parts of the Polish-Lithuanian Commonwealth dramatically increased the number of Protestant subjects in the empire. ${ }^{9}$ Starting in the second half of the eighteenth century, the invitation to settle as colonists drew not only Lutherans, but also members of the Reformed Church, Mennonites, Baptists and other Protestants to Russia. ${ }^{10}$ In the military and state administrations, too, many of the highest positions were occupied by Lutherans.

At an institutional level, Protestant ideas stimulated changes in the relationship between church and state in the Petrine Era. The "Spiritual Regulation" written by Feofan Prokopovich was inspired by Protestant models," as were the high state holidays in honor of the Tsar introduced by Peter I. ${ }^{12}$ In accordance with the Protestant understanding of the position of the ruler, the Tsar became the head of the Protestant congregations in Russia. ${ }^{13}$ In addition to close ties with universities in Jena, Leipzig and Halle from the Petrine Era, new connections were made in the second half of the eighteenth century to other Protestant universities, such as those in Göttingen. ${ }^{14}$

Smilianskaia, Volshebniki, bogokhul'niki, eretiki: Narodnaia religioznost' $i$,dukhovnye prestupleniia' $v$ Rossii XVIII v. (Moscow: Inarik, 2003), 265-9.

${ }^{5}$ Rothe, Religion und Kultur in den Regionen des russischen Reiches im 18. Jahrhundert. Erster Versuch einer Grundlegung, 18-19; on the activities of the Halle Pietists cf. Ernst Benz, "Die Beziehungen des August-Hermann-Francke-Kreises zu den Ostslaven," in Max Vasmer, ed., Festschrift für Dmytro Čyževskyj zum 6o. Geburtstag am 23. März 1954 (Wiesbaden: Harrassowitz, 1954), 76-99.

6 Claus Scharf, “'Aufklärung von oben'." Das Russische Reich,” in Wolfgang Hardtwig, ed., Die Aufklärung und ihre Weltwirkung (Göttingen: Vandenhoeckh \& Ruprecht, 2010), 169-202, here 190; Marc Raeff, "Transfiguration and Modernization: The Paradoxes of Social Disciplining, Paedagogical Leadership, and the Enlightenment in Eighteenth-Century Russia," in Ernst Hinrichs, Hans-Erich Bödeker, eds., Alteuropa, Ancien Regime, Frühe Neuzeit, Probleme und Methoden der Forschung (Stuttgart: Frommann-Holzboog, 1991) 99-116, here 109-112.

7 Erik Amburger, Geschichte des Protestantismus in Russland (Stuttgart: Evangelisches Verlagswerk, 1961), 38-62.

${ }^{8}$ Michael Schippan, Die Aufklärung in Russland im 18. Jahrhundert (Wiesbaden: Harrassowitz, 2012), 778.

${ }^{9}$ Amburger, Geschichte des Protestantismus in Russland, 58-9.

${ }^{10}$ Paul W. Werth, The Tsar's Foreign Faiths. Toleration and the Fate of Religious Freedom in Imperial Russia (Oxford: Oxford University Press, 2014), 29.

"Polnoe Sobranie Zakonov Rossiiskoi Imperii, vol. 6, no. 3718 (1721); Igor Smolitsch, Geschichte der russischen Kirche 1700-1917, vol. 1 (Leiden: Brill, 1964), 118-120.

${ }^{12}$ V. M. Zhivov, B. A. Uspenskii, “Car' I Bog. Semioticheskie aspekty sakralizacii monarcha v Rossii”, in Iazyki kul'tury I problemy perevodimosti (Moscow: Nauka, 1987), 47-153, here 118.

${ }^{13}$ V. M. Zhivov, B. A. Uspenskii, “Car' i Bog. Semioticheskie aspekty sakralizacii monarcha v Rossii,” 93.

${ }^{14}$ Rothe, Religion und Kultur, 17-19. 
The Orthodox Church had begun to confront the ideas of the Reformation and Protestant teachings in the sixteenth century. ${ }^{15}$ In the late seventeenth and early eighteenth centuries, Ukrainian clergy were particularly active in these debates, drawing on the experiences of the Counter-Reformation in Poland-Lithuania. Similarly, Stefan Iavorskii, administrator of the patriarchate, offered a refutation of Protestant dogma in his treatise "The Rock of Faith" (Kamen' very). ${ }^{16}$ During the debate surrounding this anti-Protestant pamphlet, German Evangelical theologians were called upon to respond and they wrote rebuttals defending the Protestant position. ${ }^{17}$ "The Rock of Faith" could not be published until 1728, after the deaths of Peter I and Catherine I. ${ }^{18}$

The concern about Protestant teachings in the early eighteenth century was inspired not so much by a fear of the expansion of Protestantism, but by a fear of heresies within the Orthodox Church. Thus, these debates were part of the fight against freethinking. This contrasted with the much stricter attitude regarding the Catholic Church: here, because of the existence of the Uniate Church, it was particularly necessary to maintain a sharp distinction between Orthodoxy and Catholicism. ${ }^{19}$ The anti-Protestant polemics began to die down towards the middle of the century, when the perception of Protestantism was no longer linked with attitudes about the reforms of Peter I and the issue of whether Germans were asserting a dominant influence in Russia.

The inspiration of Protestantism particularly came from one core idea of the Reformation: the doctrine of a "priesthood of all believers" and the requirement derived from this that both clergy and believers should be educated and knowledgeable about the Bible. Both the efforts to increase the level of education among the clergy and the development of pastoral training and theology can be interpreted as a response to Protestant teachings. ${ }^{20}$ German as a foreign language was taught in theological seminaries. ${ }^{21}$ Protestant sermons were translated into Russian and included in a collection of sample sermons from 1775, which was meant to serve as

\footnotetext{
${ }_{15}$ Müller, Die Kritik des Protestantismus in der russischen Theologie vom 16. bis zum 18. Jahrhundert; Vasilios N. Makrides, "Ohne Luther. Einige Überlegungen zum Fehlen eines Reformators im orthodoxen Christentum," in Hans Medick, Peer Schmidt eds., Luther zwischen den Kulturen (Göttingen: Vandenhoeckh \& Ruprecht, 2004), 318-36, here 327.

${ }^{16}$ This text was written in the context of the trial of Tveritinov. Cf. Müller, Die Kritik des Protestantismus in der russischen Theologie vom 16. bis zum 18. Jahrhundert, 68-78.

${ }^{17}$ Schippan, Die Aufklärung in Russland im 18. Jahrhundert, 81-87; Müller, Die Kritik des Protestantismus in der russischen Theologie vom 16. bis zum 18. Jahrhundert, 79-81. For additional information on Stefan Iavorskii, see: Robert Collis, The Petrine Instauration. Religion, Esotericism and Science at the Court of Peter the Great, 1689-1725 (Leiden: Brill, 2012), 211-70.

${ }^{18}$ Smilianskaiia, Volshebniki, bogokhul'niki, eretiki, 320.

19 Werth, The Tsar's Foreign Faiths, 33-5; Smilianskaia, Volshebniki, bogokhul'niki, eretiki: Narodnaia religioznost' $i$,dukhovnye prestupleniia 'v Rossii XVIII v., 246-7, 265-326; Aleksandr Andreev, "Pravoslavno-protestantskie otnosheniia v Rossii v XVIII v.," Voprosy istorii 8 (2012): 83-95, here 86-7, 93. ${ }^{20}$ Smilianskaia, Volshebniki, bogokhul'niki, eretiki: 326.

${ }^{21}$ Ekaterina Kislova, "Le français et l'allemand dans l'éducation religieuse en Russie au XVIIIe siècle," ВИВЛІОӨИКА: E-Journal of Eighteenth-Century Russian Studies, vol. 1 (2013): 48-74; eadem, "Deutsch als Sprache der Aufklärung in den russischen Seminarien im 18. Jahrhundert,” in Albrecht Beutel, Martha Nooke, eds., Religion und Aufklärung. Akten des Ersten Internationalen Kongresses zur Erforschung der Aufklärungstheologie (Münster, 2014), (Tübingen: Mohr Siebeck, 2016), 327-336.
} 
guidance when preaching. ${ }^{22}$ The schoolbook for the empire's schools, entitled "About the duties of man and citizen" ( $O$ dolzhnostiakh cheloveka i grazhdanina), disseminated Protestant teachings about duty. ${ }^{23}$ So many writings by German Protestant authors were translated into Russian that they heavily dominated the religious literature available in translation. ${ }^{24}$ Starting in the mid-eighteenth century, Church leaders strove to eradicate superstition and "purify" the Orthodox Church in line with the spirit of the Protestant Reformation. ${ }^{25}$

This journal issue is dedicated to a central concern of Protestant doctrine religious education - as it was acted upon in the eighteenth and early nineteenth centuries. Here the Orthodox Church, lacking writings of its own on the matter, had, as Gregory Freeze has put it, "little choice but to borrow from the Lutheran models." 26

The contributions in this cluster look at the translation of children's literature (Vitalii Simankov) and offer an overview of the catechisms that were created based on Protestant models (Margarita Korzo). Through the close analysis of the works of Bishop Tikhon of Zadonsk, who was deeply influenced by Johann Arndt's "Four Books on True Christianity" (Vier Bücher vom wahren Christentum), ${ }^{27}$ they examine the reception of Protestant teachings by ranking prelates of the Church (Andrey Ivanov). And they explore the history of the scriptural "Reformation" ${ }^{28}$ in Russia (Barbara Skinner).

Translated by Brenda Black

\footnotetext{
${ }^{22}$ Gavriil (Petrov), Platon (Levshin), Sobranie raznykh uchenii na vse voskresnye i prazdnichnye dni, 3 vols. (Moscow, 1775); V. M. Zhivov, Iazyk i kultura v Rossii XVIII veka (Moscow: Iazyki russkoi kul'tury, 1996), 397-400.

${ }^{23}$ O dolzhnostiakh cheloveka i grazhdanina. Kniga $k$ chteniiu opredelennaia $v$ narod- nykh gorodskikh uchilischakh Rossiiskoi imperii (St. Petersburg: Tipografiia Akademii nauk, 1783).

${ }^{24}$ Horst Röhling, "Observations on Religious publishing in Eighteenth-Century Russia”, in Roger P. Bartlett, Anthony Cross, Karen Rasmussen, eds., Russia and the World of the Eighteenth Century (Columbus, Ohio: Slavica, 1988), 91-110, here 95-97; Michael Schippan, "Retseptsiia protestantskikh avtorov v Rossii v XVIII veke (Spalding, Crugot, Stender),” in Roger Bartlett, Gabriela Lehmann-Carli, eds., Eighteenth-Century Russia: Society, Culture, Economy. Papers from the VII International Conference of the Study Group on Eighteenth-Century Russia, Wittemberg 2004 (Berlin: LIT, 2007), 237249.

${ }^{25}$ Müller, Die Kritik des Protestantismus in der russischen Theologie vom 16. Bis zum 18. Jahrhundert, 83.

${ }^{26}$ Freeze, Lutheranism in Russia: Critical Reassessment, 307.

${ }^{27}$ Stefan Reichelt, "Retseptsiia tvorchestva Ioanna Arndta v Rossii v XVIII veke," in Bartlett, LehmannCarli, eds., Eighteenth-Century Russia: Society, Culture, Economy, 221-8; idem, Johann Arndts Vier Bücher von wahrem Christentum in Russland. Vorboten des neuzeitlichen interkulturellen Dialogs (Leipzig: Evangelische Verlagsanstalt, 2011).

${ }^{28}$ Into the mid-eighteenth century, the psalter remained the most popular book of the Bible and was often the only textual source of Bible knowledge for many. The New Testament was largely unknown, being printed only 17 times before 1750 . The psalter, in contrast, was printed 90 times before 1700 . Cf. Rothe, Religion und Kultur in den Regionen des russischen Reiches im 18. Jahrhundert. Erster Versuch einer Grundlegung, 13-14.
} 